\title{
RESEARCH STRATEGIES FOR ORGANIZATIONAL HISTORY: A DIALOGUE BETWEEN HISTORICAL THEORY AND ORGANIZATION THEORY
}

\author{
MICHAEL ROWLINSON \\ Queen Mary University of London \\ JOHN HASSARD \\ University of Manchester \\ STEPHANIE DECKER \\ Aston University
}

\begin{abstract}
If history matters for organization theory, then we need greater reflexivity regarding the epistemological problem of representing the past; otherwise, history might be seen as merely a repository of ready-made data. To facilitate this reflexivity, we set out three epistemological dualisms derived from historical theory to explain the relationship between history and organization theory: (1) in the dualism of explanation, historians are preoccupied with narrative construction, whereas organization theorists subordinate narrative to analysis; (2) in the dualism of evidence, historians use verifiable documentary sources, whereas organization theorists prefer constructed data; and (3) in the dualism of temporality, historians construct their own periodization, whereas organization theorists treat time as constant for chronology. These three dualisms underpin our explication of four alternative research strategies for organizational history: corporate history, consisting of a holistic, objectivist narrative of a corporate entity; analytically structured history, narrating theoretically conceptualized structures and events; serial history, using replicable techniques to analyze repeatable facts; and ethnographic history, reading documentary sources "against the grain." Ultimately, we argue that our epistemological dualisms will enable organization theorists to justify their theoretical stance in relation to a range of strategies in organizational history, including narratives constructed from documentary sources found in organizational archives.
\end{abstract}

Organization theorists increasingly agree that "history matters," both for understanding ourselves (Brown \& Hörtel, 2011) and for understanding organizations (Sydow, Schreyögg, \& Koch, 2009). New institutionalists in particular have continually affirmed the importance of his-

We thank Frances Bowen, Andrew Brown, Nancy Campbell, and Sadhvi Dar, as well as editor Roy Suddaby, associate editor Rick Delbridge, and three anonymous AMR reviewers, for their constructive comments on earlier versions of this manuscript. We received valuable feedback on our work in progress from the Management History Research Group, the EGOS SWG on Historical Perspectives in Organization Studies, the Centre for Management and Organizational History Workshop (2011) at Queen Mary University of London, a Newcastle University Business School seminar (2012), and the OAP Workshop on Time, History and Materiality in Management and Organization Studies (2013) at the London School of Economics. tory for understanding organizations (Tolbert \& Zucker, 1983: 36). But even new institutionalists have a tendency to become ahistorical (Suddaby, Foster, \& Mills, 2014), and organization theorists in general tend to share the general social scientific skepticism toward archival narrative history (Sewell, 2005: 225). It has even been suggested that consulting organizational archives is "not properly a method of empirical organizational research because data and information are collected, rather than being directly generated in the course of the organizational research" (Strati, 2000: 133-134). Or history is regarded as prosaic storytelling, with the implication that we can relax our critical, skeptical faculties when reading history (Down, 2001), and historical narratives can simply be incorporated to illustrate theoretical arguments. 
Organization theorists have yet to acknowledge the implications from historiography, as "the writing of history and the study of historical writing," that there are many different kinds of history (Jordanova, 2006: 228). The "historic turn" (McDonald, 1996; Sewell, 2005: 81-82) has opened a dialogue between the humanities and wider social sciences, including organization theory (Booth \& Rowlinson, 2006; Clark \& Rowlinson, 2004; Wadhwani \& Bucheli, 2014; Zald, 1996). But, to paraphrase Hayden White (1987: 164), a leading philosopher of history, if we are going to turn to history, we need to have a clear idea of the kind of history we mean and whether it can accommodate our values as organization theorists. According to White, "The function of theory is to justify a notion of plausibility" (1987: 164). Therefore, we need a theoretical stance that can justify the plausibility of any history we construct from historical sources; otherwise, the possibility for a conversation with historical theory will be precluded by a "common sense" definition of organizational history. Without a theoretical stance, organization theorists may be seen as unwelcome tourists, "wandering around the streets of the past" (White, 1987: 164) looking for a set of data. Or, as Kuhn put it, history needs to be seen as more than merely a repository for "anecdote and chronology" (1970: 1).

In order to reflect on what we mean by "organizational history," we need to have a better idea of the varieties of history that are feasible for organizational research and writing. Philosophers of history have highlighted the variety of history as a response to what Paul Ricoeur calls the epistemological "problematic of the representation of the past" (2004: xvi). According to Chris Lorenz (2011), the epistemological problems for history mainly concern the status of narrative, the nature of evidence, and the treatment of time. Responding to this problematic, in the first part of our article we propose three epistemological dualisms-that is, different ways of "knowing" the past that tend to differentiate historians from organization theorists. These dualisms explain the reluctance of organization theorists to research and write narrative history derived from primary documentary sources found in organizational archives.

In the dualism of explanation, historians are preoccupied with the epistemological problems of narrative construction, whereas organization theorists subordinate narrative to analysis. In the dualism of evidence, historions use norrative history derived from eclectic but verifiable documentary sources, whereas organization theorists prefer data constructed from replicable procedures. And in the dualism of temporality, historians continually construct periodization from sources and historical contexts, whereas organization theorists tend to treat time as constant or else import periodization as given from historiography. These dualisms provide a template that we can use to assess alternative strategies for historical research and writing.

In the second part of the article, we use our epistemological dualisms to identify and analyze four alternative strategies for research and writing organizational history derived from organizational archives: corporate history, consisting of a holistic, objectivist narrative of a named corporate entity; analytically structured history, in which conceptually defined structures and events are narrated, such as Chandler's (1962) accounts of structural reorganization; serial history, using replicable techniques to analyze repeatable facts; and, finally, ethnographic history, derived from reading sources "against the grain" in order to recover practices and meanings from organizations. These four strategies illustrate the variety of research that is feasible using historical sources generated by organizations themselves. This serves to counter what we see as the reluctance to use "organizational archives" in organization studies, which is not to say that organizational history can only be written using such archives. But in our view organizational archives are not only underutilized for constructing data in organization studies; as documentary sources, they also represent evidence that remains largely unexplained by organization theory.

This article thus contributes to organization theory by identifying a range of theoretical stances in relation to organizational history. We also set out the epistemological problems that organization theorists need to consider when deciding how to construct, incorporate, or analyze historical norratives derived from archival sources. From our epistemological dualisms, organization theorists will be able to articulate why it is that history matters, and from our research strategies for organizational history, they will be able to answer the question "What kind of history am I writing?" or "What kind of history am I reading?" 


\section{HISTORICAL THEORY AND ORGANIZATION THEORY}

There have been repeated calls for more history in management education (Cummings \& Bridgman, 2011; Madansky, 2008; Smith, 2007; Van Fleet \& Wren, 2005) and a historical perspective in organization theory (Aldrich, 1999; Bucheli \& Wadhwani, 2014; Kieser, 1994; Üsdiken \& Kieser, 2004; Zald, 1993). Stager Jacques (2006: 44) has argued that "historically informed theorizing" requires a more rigorous approach to historical methodology. But historiography has yet to receive the same systematic analysis in organization theory as, for example, theorizing from case studies (Eisenhardt, 1989), process (Langley, 1999) or narrative (Pentland, 1999) data, and other interpretive approaches (Prasad \& Prasad, 2002). While those using these approaches occasionally incorporate historical data constructed from organizational archives, they remain skeptical toward historical narratives, and these approaches are not predicated on the kind of dialogue with historical theory that we propose.

We cannot look to practicing historions for a guide to historically informed theorizing in the same way that we might look to practitioners in other disciplines. History in general is more "craftlike" than the social sciences, which means that explicit theoretical or methodological statements are not necessarily required for historical writing (White, 1995: 243), especially for norrative history. There is indeed a long-standing "resistance to theory" from practicing historians (Lorenz, 2011: 15-16; see also Fulbrook, 2002: 25). But in the relatively separate field of historical theory, the implicit theoretical assumptions that underpin the "craft" of history have been explicated, either to provide legitimation for accepted historiographical proctice or to critique it (e.g., Clork, 2004; Jordonova, 2006; Lorenz, 2011: 15).

From the outset, we recognize that dualism is implicit in history. According to Hegel, "The term History unites the objective with the subjective side,... it comprehends not less what has happened, than the narration of what has happened" (1956, quoted in White, 1987: 11-12). It is generally accepted, therefore, that history covers "(1) the totality of past human actions, and (2) the narrative or account we construct of them now" (Walsh, 1967: 16, quoted in Callinicos, 1995: 4; see also Sewell, 2005: 327). As a result of this "double meaning," we can make a distinction between ontological theories that refer to "history as an object" and epistemological theories concerned with "knowledge of that object" (Lorenz, 2011: 20). Organization theorists tend to assume that a theory of history refers to the ontology of history, whereas historical theorists are generally more concerned with the implications of historical epistemology. So to say that "history matters" in organization theory usually means that past human actions are seen as ontologically significant for path dependence (e.g., Sydow et al., 2009). Equally, it could be said that "history matters" epistemologically for understanding how the past can be known or represented, either directly, through organizational research and writing, or through historiography.

Previous proposals for historical research in organization studies (Goodman \& Kruger, 1988; Kieser, 1994; Lawrence, 1984) have been predicated on a definitive, unitary statement of historical method. But we maintain that alternative strategies for research and writing organizational history need to be located in relation to the range of ontological, epistemological, and methodological assumptions identified by historical theory (Lorenz, 2011). As a starting point, our three epistemological dualisms locate organization theory in relation to historiography.

\section{Dualism 1: Explanation (Narrative and Analysis)}

The renewed interest in history from new institutionalists (Rowlinson \& Hassard, 2013; Suddaby et al., 2014; Suddaby, Foster, \& Trank, 2010) is associated with increasing attention to actors and agency in institutional work (Lawrence, Suddaby, \& Leca, 2009) and in institutional logics (Thornton, Ocasio, \& Lounsbury, 2012). New institutionalists recognize the difficulty of restoring a role for actors and agency without reverting to "powerful, heroic figures" who can transcend institutional constraints (Lawrence et al., 2009: 3). Similarly, theoretically oriented historians and sociologists, following a self-conscious logic that posits "intentionality, contingency, and meaningful human action" (Lorenz, 2011: 21), are mindful that they risk licensing a resurrection of the "great man" theory of history (Sewell, 2005: 316). This is the unstated default theory for most historians who claim they "have no time for theory" (Fulbrook, 2002: 125). A shift of emphasis from structure to 
agency is associated with a return to narrative in historiography (Stone, 1979; see also Fulbrook, 2002: 53), although historians recognize that theoretically informed history is supposed to "avoid narrative" in favor of "thematic analysis" (Evans, 1997: 152).

Following the example of Giddens (1984: 355363) in historical sociology, a convergence in relation to the dualism of action and structure could be held as evidence that there is no logical or methodological schism between organization theory and history: organization studies are, or can be, historical, and vice versa, and therefore organizational history simply refers to a unified field. However, from the historians' side, it would be difficult to see such a synthesis as anything but another imperialistic incursion into history (Evans, 1997: 182). Furthermore, the ontological dualism of action and structure should not be conflated with the epistemological dualism of narrative and analysis in explanation, not least because, according to Ricoeur (1990: 197), structural history often turns out to be a narrative of quasi-characters such as nations, classes, or organizations intentionally pursuing their own interests.

The objections to narrative construction have been rehearsed by such historical theorists as Allan Megill, who has argued that the "scientistic form of anti-narrativism" prevalent in social science insists on "the language of law and theory, not the language of narrative" (2007: 68-69; see also Sewell, 2005: 225). Whether or not organization theory can be characterized as anti-narrativist, major organizational research programs, such as organizational ecology, are "formally probabilistic" (Hannan \& Freeman, 1989: 40) and mostly expressed in a theoretical rather than norrative form. This is not to say that norrative and probabilistic reasoning are mutually exclusive, since they can offer complementary accounts of the same phenomenon (Megill, 2007: 126).

Popper argued that history is concerned with "the causal explanation of a singular event," whereas for "theoretical sciences, such causal explanations are mainly means to a different end-the testing of universal laws" (2002/1957: 133). Similarly, but from a completely different historical perspective, the classicist Paul Veyne asserted that we can treat a fact as an event "because we judge it to be interesting," or we can look for its "repeatable nature" as a "pretext for discovering a law" (1984: 3). In organization theory, nar- rative explanations of singular historical events are usually seen as stepping-stones toward the development of generalizable theories (cf. Eisenhardt, 1989; Langley, 1999), and even supposedly idiographic case studies are seen as a vehicle for identifying "generative mechanisms" (Tsoukas, 1989). Popper (2002/1957: 90), of course, was clear that the "method of generalization" holds little interest outside of theoretical sciences, and it is not the kind of history he wished to write. But that does not preclude the use of general theories in the construction of narratives to explain singular events. There is no reason why theories of organization, such as new institutionalism, should not be promoted more widely for constructing narrative organizational histories.

Narrative history also faces what philosophers of history call the "impositionalist objection," according to which "recounting the past in the form of a story inevitably imposes a false narrative structure upon it" (Norman, 1998: 156; see also Carr, 1998). The resistance to writing up qualitative social science research in a narrative form (Riessman, 2011: 314) derives from the impositionalist objection to narrative. Martin, for example, consciously "avoids narrative structure and other forms of textual seduction" in her writing (1992: 25). Taking more account of agency and meaning in organization theory, as in new institutionalism, has led to increasing recognition that narratives are amenable to deconstruction (Boje, 1995) or analysis as data (Barry \& Elmes, 1997; Hardy \& Maguire, 2010; Lawrence \& Suddaby, 2006: 240; Pentland, 1999). Organization theorists also recognize the ontological status of narrative as constituting objects, or "artifacts" (Venkataraman, Sarasvathy, Dew, \& Forster, 2013), that "enable and constrain" individuals and organizations (Pentland, 1999: 721). But since narrative analysis takes stories as the "object of investigation" (Riessman, 1993: 1), it has, if anything, reinforced the impositionalist objection to norrative construction in organization theory.

Unfortunately, the default position for craft historians can be characterized as a form of objectivism, or "historical realism," where history is seen as an "untold story" that exists independently and prior to being discovered and told by the historian (Norman, 1998: 155). Peter Novick's acclaimed history of objectivity in the American historical profession starts with an outline of "objectivism" rather than objectivity 
itself. Objectivism consists of "a commitment to the reality of the past, and to truth as correspondence to that reality; a sharp separation between knower and known, between fact and value, and, above all, between history and fiction" (Novick, 1988: 1-2). Objectivists assume that historical facts exist "prior to and independent of interpretation," and "whatever patterns exist in history are 'found,' not 'made"' (Novick, 1988: 1-2). Objectivist history is clearly inimical to the kind of reflexivity that would be required to counter the impositionalist objection to narrative through a self-conscious account of the theoretical and methodological assumptions that underpin its own narrative construction. Objectivism therefore provides a convenient strawman for critics of historical practice (e.g., Barrett \& Srivasta, 1991; Munslow, 2012), and objectivist history unwittingly supplies the kind of narrative that is amenable to analysis as "rhetorical history" (Suddaby et al., 2010).

Organization theorists (e.g., Hardy \& Maguire, 2010: 1368) and historical theorists (e.g., Fulbrook, 2002) share a minimal definition of narrative, derived from narrative theory (Cobley, 2001), as a sequence of logically and chronologically related events organized by a coherent plot. This does not mean that events have to be presented in chronological order, and a simple chronological sequence of events is often seen as insufficient to constitute a narrative, being described as a "chronicle" (White, 1987: 17) or "a story without a plot" (Czarniawska, 1999: 63). If the story consists of all the events depicted and the plot is the chain of causation linking them (Cobley, 2001: 5), then the question for historical narratives is whether either or both the story or the plot are found or imposed. Historical theorists have focused on "emplotment" in historical narratives, with the plot determining the selection of "facts" and the construction of events from the archives, and an acceptance that the same "historical facts" can be emplotted in different forms of narrative (Fulbrook, 2002: 8).

Megill has noted that narrative history has also been criticized for being excessively descriptive (2007: 86) or having too much story and not enough plot (Czarniawska, 1999: 69). Langley, for example, acknowledged the value of norrative for capturing the richness of a context but argued that research needs to "offer more explicit theoretical interpretations" (1999: 697). She therefore cautioned against reliance on nar- rative in organizational research, because "an idiosyncratic story" makes for "a rather thin conceptual contribution" (1999: 697). Furthermore, Langley maintained that the most interesting narratives are not "purely descriptive. They know where they are going" (1999: 697).

Megill has attributed the "debasement of 'description"' to "hermeneutic naïveté," which ignores "the hermeneutic insight that all perception is perspectival" (2007: 86-87). Organization theorists share the social scientific consensus that "data are not theory" because theory requires "causal arguments" (Sutton \& Staw, 1995: 374; Weick, 1995: 387). Against this Megill has argued that "every 'description' is already permeated by 'theory'" (2007: 87). In particular, "thick description" of "a context" (Geertz, 1973: 14), purged of plot, represents a form of analysis in its own right, even if it deliberately lacks causal argument. From a self-consciously "angular perspective" (Megill, 2007: 110-111), such as Foucault's (1977), pure description can be seen as theoretical. It is also worth noting that Weber's (2009) ideal types largely consist of conceptual descriptions rather than causal arguments (Megill, 2007: 233, note 13). If alternative "styles of theorizing" (Delbridge \& Fiss, 2013) are accepted in organization studies, then historical typologies, such as Weber's ideal types, as well as clearly articulated perspectives for description in organizational history, are more likely to be recognized as theory.

Analysis lends itself to the standard format for a social science article (i.e., introduction, theory, methods, findings, conclusion), where the theory section may be presented as a narrative (DiMaggio, 1995) but not the findings. The "analytic narratives" proposed by rational choice theorists (Bates, Greif, Levi, Rosenthal, \& Weingast, 1998; Pedriana, 2005) and other forms of "narrative positivism" (Abbott, 1992) tend to present attenuated narratives, often derived from narrative analysis, and generally lack the literary features we usually expect from norrative, such as suspense (Carpenter, 2000; Sewell, 2005: 262-270). The difficulty with making the mode of emplotment explicit in norrative history is that in literature the reader usually infers the plot. Spelling out the plot in the theory section of on article, or subordinating it to rigorous logic, risks undermining the literary form of a narrative, rather like a comedian trying to explain why a joke is funny before actually telling the joke. 


\section{Dualism 2: Evidence (Sources and Data)}

Along with an aversion to historical description, qualitative organizational researchers are also wary of using historical data. Again, we can take the example of Langley, who sees "current data collected in real time" as "richer and finer grained" than "historical data collected through the analysis of documents and retrospective interviews," which she has characterized as "sparse and synthetic, focusing on memorable moments and broad trends," and only to be used out of necessity in combination with current data (1999: 693). This is understandable insofar as Langley associates historical data with "coarse-grained longitudinal time series" (1999: 691). We find that organization theorists refer to "archival data" as if they are an alternative to "qualitative research" (Shipilov, 2009: 93), and they assume that "retrospective" research using historical data is quantitative (Denrell \& Kovacs, 2008), so much so that quantitative longitudinal studies are seen as synonymous with history (Kipping \& Üsdiken, 2008). Quantitative researchers appear to be more comfortable using historical sources as secondary data, whereas qualitative researchers clearly prefer primary data that they have constructed themselves (Strati, 2000). The qualitative objections to using historical data therefore provide our focus for exploring the dualism of sources and data as evidence.

The terms sources and data are often used interchangeably, but we can make a distinction between them because it is clear that organization theorists prefer what they call primary data over secondary or historical data, whereas historians prefer primary to secondary sources. The organization theorist's secondary or historical data correspond to the historian's primary sources, and the terminological difference is not purely semantic since it reveals a deeper epistemological dualism in relation to the treatment of evidence and the notion of what constitutes a cumulative contribution to knowledge.

We can explore the reservations regarding archival data in organization studies further, given that with the renewed interest in history from new institutionalism (Suddaby et al., 2014), organization theorists have made occasional forays into archival historical sources for qualitative research. But as Rojas illustrates, when "organizational archives" are consulted, their "disadvantages" have to be rehearsed in a way that would not be expected, say, for interviews: first, "organizations vary in what is saved and when it is saved"; second, "archives tend to be rich in documents from leaders, but they have fewer materials about other actors"; and third, "actors can selectively record what transpires in an organization. Meeting minutes, for example, may address only major points and omit important contextualizing discussions" (2010: 1268). As a result, Rojas argues, "archival sources should be supplemented, when possible, with newspaper accounts, interviews, memoirs, and other materials" (2010: 1268).

Organization theorists appear to believe that the "validity and reliability" of documentary archival sources must be questioned more than constructed data, such as interview transcripts (Strati, 2000: 159). As a result, even when they are used, archival sources are cited sparingly (e.g., Rojas, 2010) and are generally relegated to providing "background information about an organization" (Strati, 2000: 158) or validating retrospective accounts (Golden, 1997), as in most case studies (Eisenhardt, 1989; e.g., Smets, Morris, \& Greenwood, 2012).

Historians are more likely to rehearse the argument that, when possible, interviews should be supplemented with documentary research so as not "to accept one's informants' statements at face value.... Documentary research provides an excellent means to test the accuracy of different images and perceptions of the organization and to compare espoused and actual values" (Dellheim, 1986: 20). But, more important, history is equated with the use of primary sources, produced at the time of the events being researched (Jordanova, 2006: 95), which means that the more contemporaneous a source is with the past in question, the higher its value for historions (Alvesson \& Sköldberg, 2009: 113). Even if the distinction between primary and secondary sources is difficult to justify at a theoretical level, it is indispensable as a "methodological rule of thumb" (Megill, 2007: 50). For historians, retrospective interviews count as "testimony," which is notoriously unreliable and almost by definition cannot constitute a primary source, especially when it is collected years later (Megill, 2007: 20, 50). Historians therefore have a strong preference for "nonintentional evidence," by which they mean "anything remaining from the past that was not made with the 
intention of revealing the past to us, but simply emerged as part of normal life" (Megill, 2007: 25, 29; see also Howell \& Prevenier, 2001).

Since historians cannot directly observe the past, they have to reconstruct it, mainly from documentary sources (Callinicos, 1995: 65). Organization theorists might argue that organizational history is no different from other subfields where constructs are not directly observable. However, constructs can be inferred from observations generated in the present, such as responses to questions. Historians are dependent on the observations that historical actors have made, which then find their way into the archives. With the exception of oral history, which mainly concerns the recent past, history stands apart from social science because historians cannot produce evidence; instead, they have to find it (Megill, 2005: 456).

From an epistemological point of view, historians can be seen as "explaining present evidence" (Megill, 2005: 454)—constructing an account of the past that can best explain the sources that have been found so far, rather than explaining the past through the sources (Megill, 2007: 246 note 15). From a historical perspective, then, the problem is not so much how to generate theory from organizational archives but, rather, how to generate narratives or theories that can explain the sources found in organizational archives. As part of the explanation for the extensive archives held by so many organizations, often tended by highly qualified archivists, we need to understand what the philosopher of history Michel de Certeau (1988) called the "historiographical operation." In the context of organizations, this refers to the process whereby the bureaucratic files are set aside and transformed into historical "documents," or, as on archivist might say, certain "records" are selected for preservation as "archives."

As Alvesson and Sköldberg (2009: 107) point out, organization theorists have largely ignored "source criticism," which constitutes a rigorous method for interpreting sources that could counter the skepticism toward organizational archives. Source criticism distinguishes between social "documents" and narrative or literary "texts" (Howell \& Prevenier, 2001: 20-21). As record-keeping bureaucracies, organizations produce social documents, such as board minutes and personnel records, as well as narrative texts, such as annual reports and in-house mag- azines, which have been used to examine culture and change in organizations (e.g., Mills, 2006; Neimark, 1992). Yates's (1989) historical account of communication in American management from 1850 to 1920 represents an innovative explanation for the form of evidence found in organizational archives.

Historians are also used to reading sources "against the grain" (Clark, 2004: 126; Evans, 1997: 143; Gunn, 2006: 169), inferring a meaning beyond, or even opposed to, what the sources were intended to mean. Even testimony can be "made to reveal what it doesn't itself say" (Dray, 1986: 34). As Ginzburg explains in the preface to his celebrated study of sixteenth-century Italian popular culture, "The fact that a source is not 'objective' ... does not mean that it is useless. A hostile chronicle can furnish precious testimony about a peasant community in revolt" (1992/1976: xvii). Prohibition can be taken as evidence of practice. Or, as Boje (2008: 24) puts it, all texts can be read as "an answer to something," with the aim of recovering what the text was an answer to. So when we read in the Bible that Timothy would "suffer not a woman to teach, nor to usurp authority over the man, but to be in silence," a historian of Christianity assumes that there must have been women who were anything but silent (MacCulloch, 2010: 120). Since we can no longer hear their side of the argument, we have to reconstruct it from those who silenced them. As Gayatri Chakravorty Spivak (1988), the postcolonial theorist, argued, partly on the basis of research in the archive of the East India Company, if the subaltern presence in history is to be recovered, then the silence of the archives needs to be recognized-what the sources do not say may be as important as what they do say (Decker, 2013).

The objections to using organizational archives can be attributed to confusion over the nature of sources and how they can be read. When historians refer to archival sources, they usually mean the unique, noncirculating social documents that they have diligently found, often in an archive that can only be consulted at a particular location by special permission (Hill, 1993: 22-23). Most social documents bear little resemblance to narrative literary texts (Evans, 1997: 111). But qualitative organizational researchers seem to assume that historical sources mainly consist of published narrative texts, such as books, magazines, and newspa- 
pers (Denzin \& Lincoln, 2000). Historical research is then equated with a detailed analysis of a sample of these narrative texts (e.g., Arndt \& Bigelow, 2005; Shenhav \& Weitz, 2000), which can then be treated as if they were constructed data, such as interview transcripts.

Organization theorists may argue that organizational archives are "collected, processed and expounded according to the organization's criteria and for the purposes of social legitimation" (Strati, 2000: 158). However, this objection applies more to the narrative texts preferred by organization theorists rather than to the "nonintentional" social documents produced in the process of running an organization. We cannot say that social documents are always more valuable than narrative sources (cf. Alvesson \& Sköldberg, 2009: 113). Nevertheless, we can say that a narrative constructed in the first instance from primary social documents, such as the minutes of meetings and their accompanying files, is less susceptible to incorporating a narrative from the past as if it were an original historical narrative of the past. Narrative historical sources themselves are emplotted-that is, they tell a story (Zieman \& Dobson, 2009: 10)—and therefore it is difficult to avoid the problem of "narrative contagion" (Alvesson \& Sköldberg, 2009: 115), whereby the plot from narrative sources is imported into the construction of $a$ historical narrative. On the other hand, narrative sources, such as periodicals, are more amenable to the replicable procedures of narrative analysis (Shenhav, 1999) than social documents. Whether qualitative or quantitative, the use of coding and content analysis objectifies sources as data and represents an epistemological attempt to ground historical interpretation in a systematic analysis of selected texts (Scott, 1990: 32).

Given that, epistemologically, historians are "explaining the evidence," it follows that they are obliged to put their evidence and reasoning "on the table" (Megill, 2007: 124), and they do this by following the "rules of verification" (Evans, 1997: 127). Unfortunately, as historical theorists admit, these rules are "unexplicated" (Fulbrook, 2002: 186), but they are usually manifest in the copious footnotes that characterize historical writing (Hexter, 1998). Historical theorists generally reject the argument that these are merely "rhetorical devices," designed to give history a spurious "reality effect" (Fulbrook, 2002: 56). His- torians maintain that detailed citations "really do enable the reader to check the sources on which a historian's statement is made and to whether or not they support it" (Evans, 1997: 127). They are a hallmark of accepted practices for historical writing, rather than an actual method for conducting research. Nevertheless, we must remember that verification of sources does not constitute validation of a narrative (Wertsch, 2011: 26), which requires further epistemological reasoning.

Historians appear to see historical theory and methodology as being analogous to the plumbing in a building, where the form should conceal its function (Gaddis, 2004: xi). They assume the plumbing is there and in good working order, but they do not want to be confronted with it in "regular historical works" (Megill, 2007: 150). If history is to be written in the form of a social science article for organization theory, then the plumbing needs to be exposed for inspection. This means that the tacit practices of "source criticism" (Alvesson \& Sköldberg, 2009: 107-116) used to identify and interrogate sources would have to be made explicit in a dedicated discussion of methods prior to the actual historical account, instead of being obscured in cryptic footnotes (Grafton, 1997).

If we accept that there is a "literary" or "fictive" element in all historical (Megill, 2007: 185) and scientific writing (Bedeian, 1997), then we can see that it takes different forms. Objectivist historians still hold to the "fiction of an objective narrator" (Megill, 2007: 87). But the "rules of verification" in history preclude the fictionalized typicality permitted for organizational case studies, which rest on very different expectations of verisimilitude where researchers are less constrained to put their evidence on the table. As Czarniawska observed, researchers often present findings for an organization that "may not exist, and yet everything that is said about it may be true," which is taken to mean that "it may be credible in the light of other texts" (1999: 38). So in a typical real-time, longitudinal, qualitative case study (e.g., Jarzabkowski, Matthiesen, \& Van de Ven, 2009), all data that might reveal the identity of the case study organization, such as "specific dates, names, products, and other contextual features" (Jarzabkowski et al., 2009: 290-291), are disguised in order to preserve anonymity. We are assured that "the nature and temporal sequence of 
events are faithfully reproduced" (Jarzabkowski et al., 2009: 290-291). However, nothing can be verified from the actual text of the case study.

To clarify the difference between data and sources, we can say that organization theorists often tell us exactly how their data were constructed for case studies but offer no clues as to where the sources for the data are located, whereas narrative historians generally tell us exactly where their sources are located but give no indication of how they found or emplotted them. A typical organizational case study may use archives, but it is predicated on a "replication logic" (Eisenhardt, 1989), whereby the procedure for constructing the data has to be specified so that it can be replicated to test the findings in another case study. In contrast, a typical narrative history is predicated on a verification logic, whereby the exact location of sources has to be given so that they can be consulted to verify whether they support the historian's emplotment. A generalizable contribution to organization theory requires replicable data, even if its fictionalization precludes verification, whereas a contribution to historiography requires verifiable sources, even if it comes in a literary norrative form without explicit theory or methods.

\section{Dualism 3: Temporality (Periodization and Chronology)}

Organization theorists recognize that time, or the timing of events, represents "an important contingency factor" that is neglected in "crosssectional research designs" (Haveman, 1993: 867). The "time elapsed" between specified events in an organization and the timing of those events in the "organizational life cycle" allow for models that "investigate history dependence" (Haveman, 1993: 867). But these models tend to equate history with time, which means that even distant historical settings are chosen because a complete data set has been found to test the generalizability of a theory (Haveman, 1993: 869-870), and not because of questions arising from historiography. As Aldrich put it, in organizational life cycle models, "'time' runs on a universal clock rather than being historically situated," which means that the models "implicitly treat one year in the 19th century as equivalent to one year in the 20th century. Problems are problems, regardless of the century in which they are encountered" (1999: 205).
In the treatment of time, therefore, a dualism can be discerned that separates history from organization theory. Dates are obviously a hallmark of most historical writing, but dating an event is not only a matter of specifying its temporal relation to other events in the same account, which could be done by referring to $t 0, t l$, t2 ... th (cf. Langley, 1999; Ricoeur, 1990: 154). Instead, a date can substitute for a more detailed account of the historical context, which is taken as given depending on the assumed background knowledge of readers (Dray, 1986: 28). In addition, particular years, such as 1865, 1945, or 1968, resonate in national collective memories.

Saying that time matters is not the same as saying that history matters. Time often matters for social scientists only in terms of specifying the chronological order of events in an account of processes such as path dependence (Abbott, 2001; Pierson, 2004), whereas history matters to historians for an understanding of events in their historical context (Tosh, 2008). Time in organization theory is therefore generally abstracted as clock time, or "analytic time" (Pedriana, 2005)—that is, as a consistent measure for the sequencing of events. But the historical context is attenuated and can be chosen without regard to its salience in historiography or collective memory. Historians generally take it as given that events are embedded in what sociologists call "temporal and spatial contexts" and in "particular social times and places" (Abbott, 1997: 1169).

The dualism of temporality differentiates chronology, where physical time is taken as constant, from periodization, where divisions of social time and space are defined from sources and historiographical context in the process of research and writing. As part of his effort to make organization theory more historical, Aldrich (1999: 206) suggested the possibility of extending evolutionary models to take account of "period effects," when "historical discontinuity" has an impact on a population of organizations. This led him to recognize the difficulty of deciding what constitutes a "period," especially when the boundaries between periods consist of "unique events." Aldrich neatly summarized the problem of identifying "discrete segments in history as 'periods,'" given that "different observers view the same events from diverse perspectives on their significance" and, in practice, "period labels" are created on the basis of dif- 
fering "research objectives and working hypotheses" (1999: 207).

When divisions of time and space are not taken as given, historians face the continual problem of devising criteria for partitioning the past into "manageable chunks" (Jordanova, 2006: 107). For a named entity, such as an organization, there is always the problem of where to start. It is necessary to distinguish between the beginning and the origin of an organization. A "beginning consists in a constellation of dated events" (Ricoeur, 2004: 139) that can be confirmed from the sources, whereas the origin or birth of an organization is a mythic event that requires a single, readily identifiable date and, preferably, an identifiable founder. This illustrates the problem that events that come to be seen as historical, as opposed to mere occurrences, are typically "composed of a series of events," with the delimitation of a historical event requiring judgment of what a narrative is attempting to explain (Sewell, 2005: 260-261). Moving from narrative to analysis can be facilitated by a periodization derived from social parameters that remain unchanged, such as rituals or structures (Abbott, 2001: 211). But periodization in history cannot be reduced to chronological clock time because it has to take into account both historical context and historiographical debate.

Organization theorists tend to see "retrospective case histories" as inherently biased (Van de Ven, 1992: 181; see also Eisenhardt \& Graebner, 2007: 28) and prone to reinforcing the myths that more disciplined longitudinal analysis can dispel (Hannan \& Freeman, 1989: 40). Real-time research may therefore be preferred to historical research because process outcomes are not known when the research commences (Van de Ven, 1992: 181). Teleology cannot be completely avoided when it comes to writing up real-time research, but history is distinguished by an inevitable irony and teleology because the ending is usually known at the beginning. For example, when we start to read a historical account of an organization, we usually know whether that organization still exists. "History appears once the game is over," as Ricoeur (1990: 157) put it, and the "retrospective intelligibility" of history cannot be predicted at the time events occur. For historians, "temporal distance" is a requirement for deciding which singular events are historio- graphically significant beyond the subjective perceptions of actors (Lorenz, 2011: 31).

Periodization also reflects the ontological commitment of historians to defining their object in time and space, or in a specific historical context, with the standard subdivisions of history's specializations being defined by period and geography (Lorenz, 2011). The specification of the object in historical time and place derives from an ontologically holistic view of history, in the sense that history is generally perceived, albeit with increasing irony, as a "singular, unified process of development" (Gunn, 2006: 172), consisting of "the entire human past" that determines or shapes "the human present and future" (Sewell, 2005: 327). This holism lends itself to on epistemological view of history as an unending accumulation of historically specific knowledge that can be integrated within a totality, equivalent to the aspiration for a unified theory in social science. In terms of temporality, therefore, history produces situated concepts of a period or an event, whereas organization theory uses clock time as a chronological measure for sequences of predefined events.

\section{RESEARCH STRATEGIES FOR ORGANIZATIONAL HISTORY}

From our epistemological dualisms we can construct a template that counterposes two stylized forms of history at opposite ends of a spectrum (summarized in Table 1). On the one hand, we find a conventional narrative organizational history, with detailed citations to primary documentary sources, and a periodization derived from sources with reference to historiography and the historical context. On the other hand, we have historically informed organization theory, derived from a clearly stated method for constructing a chronological data set from historical sources. Using this template, we can assess the potential for reconciling epistemological dualisms in alternative strategies for historical research and writing.

We have identified four historical strategies (viz. corporate history, analytically structured history, serial history, and ethnographic history) to highlight the potential for producing theoretically informed "organizational history," by which we mean the history of organizations as such, with a focus on individual organizations rather than fields or populations. Of these strate- 
TABLE 1

Epistemological Dualisms

\begin{tabular}{|c|c|c|}
\hline Dualisms & Stylized Narrative Organizational History & Stylized Historical Organization Theory \\
\hline Explanation & $\begin{array}{l}\text { Narrative of logically and chronologically related } \\
\text { events organized by a coherent plot }\end{array}$ & $\begin{array}{l}\text { Analysis of relationships between concepts and } \\
\text { categories-for example, } 2 \times 2 \text { matrices of } \\
\text { variables }\end{array}$ \\
\hline Evidence & $\begin{array}{l}\text { Sources cited from an extensive search of } \\
\text { multiple documents and texts with verifiable } \\
\text { locations in archives; verisimilitude through } \\
\text { verification logic }\end{array}$ & $\begin{array}{l}\text { Data constructed from specified replicable } \\
\text { procedure for analyzing a predefined and } \\
\text { delimited set of sources; verisimilitude through } \\
\text { replication logic }\end{array}$ \\
\hline Temporality & $\begin{array}{l}\text { Periodization of events as defined by actors or } \\
\text { historiography in historical time derived from } \\
\text { historical context and sources }\end{array}$ & $\begin{array}{l}\text { Chronology of predefined regular occurrences, with } \\
\text { sequences measured against clock/analytic } \\
\text { time-for example, event history analysis }\end{array}$ \\
\hline
\end{tabular}

gies, corporate history and ethnographic history are already recognized as historiographical genres, although our analysis underscores their distinctive characteristics. In addition, we have constructed the categories of analytically structured history and serial history, not only for the purpose of comparison but also to counter the impression that organizational history can or should be synonymous with any particular strategy.

We have selected two exemplars that illustrate the limits and possibilities for each of our four strategies (cf. Langley, 1999: 695). To facilitate a focused comparison of exemplars, we have selected journal articles (Anteby \& Molnar, 2012; Cheape, 1988; Childs, 2002; Chuong \& Baum, 2003; Freeland, 1996; Jones, 2002; McKinlay, 2002), rather than books, although in one instance we have chosen a key chapter from Chandler's (1962) classic, Strategy and Structure. The exemplars for our strategies can be summarized in terms of their approach to explanation, evidence, and temporality (see Table 2), which we expand on in the synoptic review below.

\section{Corporate History}

Organization theorists' reservations regarding organizational archives are understandable, given that most research and writing derived from such archives take the form of corporate history. We define corporate history as a holistic objectivist norrative of a named corporate entity. It is holistic in two senses: first, it generally encompasses the whole history of the entity, or at least it emphasizes continuity of the entity from its founding to the present; second, it is conceptualized as a contribution to the totality of history, filling on important gap.
The aspiration to produce a holistic continuous narrative for a corporate entity makes it necessary to search on eclectic collection of sources, with primary documentary sources given precedence whenever they are accessible. Survivor bias favors coverage of successful existing organizations enjoying relative longevity and with sufficient sources available. Corporate history also entails a teleological anticipation of future success, or occasionally failure, of the corporate entity. Although sources may be found that have theoretical significance, almost by definition it can be said that an organization is not selected for a corporate history on the basis of its potential contribution to theory, unlike an organizational case study (Eisenhardt, 1989). The focus on a named entity, rather than an event or institution, emphasizes the agency of a series of nomed individuals, even if corporate history transcends the individual agency of biography. Corporate history therefore represents the form of organizational history that most closely resembles a stylized conventional narrative history, combining narrative with documentary sources and a periodization derived from the corporate entity itself.

An important characteristic of corporate history, from the point of view of historical epistemology, is its objectivist norrative literary form, which constitutes a constraint on the ability or willingness of historians to provide a reflexive account of their perspective (Megill, 2007: 103). We find an inadvertent expression of this constraint in a well-known article by the British economic historian Donald Coleman, who argued that the only way historians can normally gain access to the archives held by extant business organizations "is to be commissioned to 


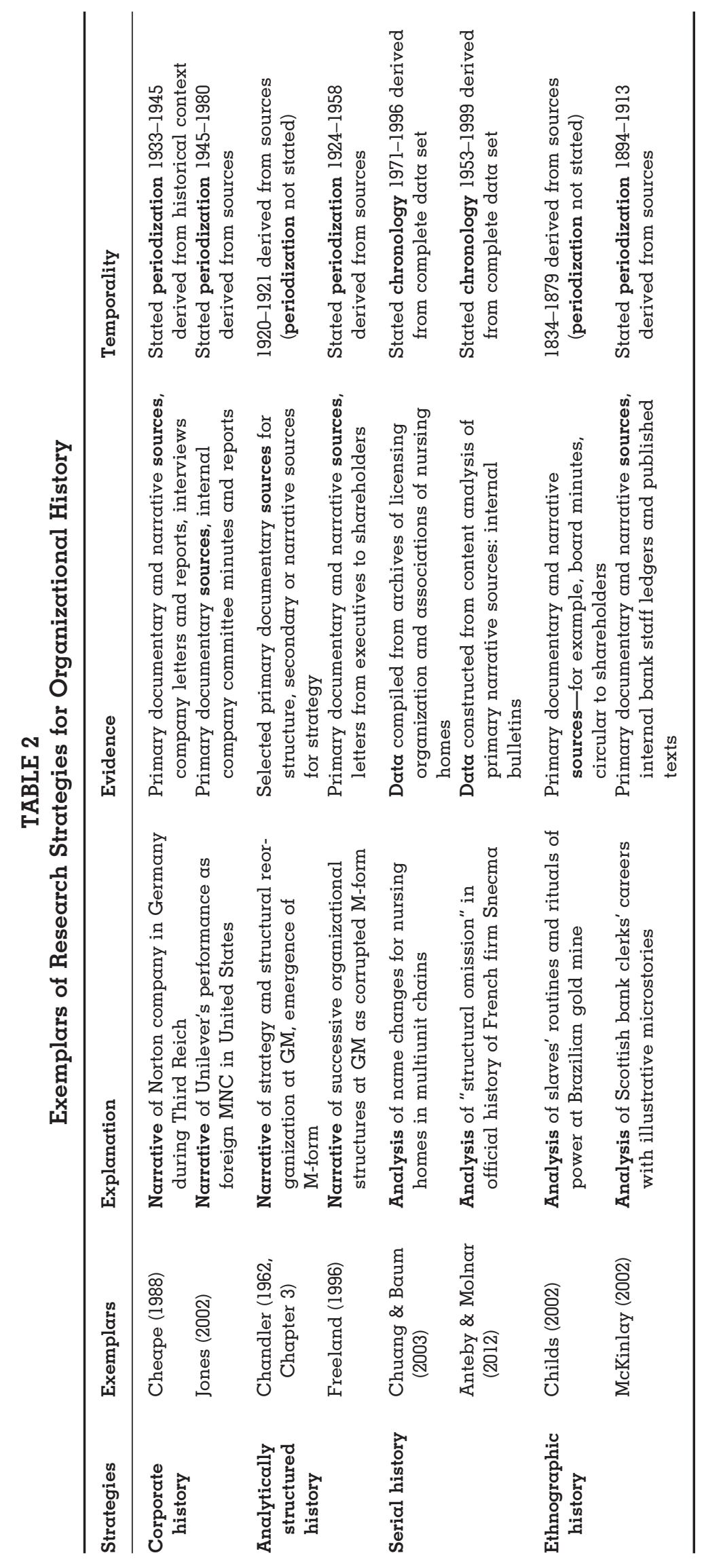


write company histories" (1987: 142). As a result, Coleman maintained that no matter how "scholarly, accurate, fair, objective and serious that company history is, its content is necessarily shaped by the need for the author to give his client something approaching what he wants. And what he normally wants is a narrative history ... warts and all maybe," but "not a comparison" with other organizations and "not an analysis" of how the organization's "behavior supports or refutes the theories of X, Y, or Z" (1987: 142). Coleman's comments reveal an interesting paradox, which is that the objectivist economic historions who are most likely to write a commissioned corporate history are, in many cases, reluctant narrativists who are most unlikely to be reflexive about questions of emplotment.

The self-imposed constraints of objectivism prevent corporate historians from reflecting on their own imposition of a narrative. This becomes obvious when considering the role of founders in corporate history. Most corporate historians would concur with Schein's (1985) view that an organization is created by a founder whose actions shape the culture of the organization. But if it is stated at all in a corporate history, rather than simply assumed, this view is expressed as a self-evident finding rather than a theoretically contested concept (Martin, Sitkin, \& Boehm, 1985). Any discussion of the "founder's role" as a mode of emplotment in corporate history is precluded by the objectivist presumption that the plot has been found rather than imposed. Objectivism is therefore a sine qua non for corporate history, and whether commissioned or not, objectivism constrains corporate history from reflecting on the imposition of a narrative, such as a foundercentered emplotment, or the possibility of any counternarrative.

As organization theorists recognize, history can confer legitimacy on organizations (Linde, 2009: 85; Suddaby et al., 2010; Suddaby \& Greenwood, 2005). The objectivist view is that legitimacy is more likely to be secured from a commissioned corporate history if it strives for "objectivity" because "reviewers and the general reader are inherently skeptical about the objectivity and balance in 'management-sanctioned' corporate histories" (Campion, 1987: 31). As a prominent academic historian who wrote a commissioned history of the Rothschild bank (Ferguson, 1998b), Niall Ferguson (1998a) made the point that neither his own reputation nor the
Rothschilds' would have been enhanced if he had written a "whitewash."

Geoffrey Jones, a professor of business history at Harvard Business School and the author of a commissioned corporate history of Unilever, the Anglo-Dutch multinational (Jones, 2005), has consistently made a distinction between "critical," "objective" commissioned histories, such as his own, and the numerous public relations company histories, which may be "readable" in a popular sense but lack "scholarly depth" (Jones, 2005: v, 323; Jones \& Sluyterman, 2003: 113). Jones (2012: 232) also appears to be a somewhat reluctant narrativist, as an advocate of using archives more critically, including the construction of databases for hypothesis testing. For his history of Unilever, Jones (2005: v) was granted "unrestricted access to archives and people," and his reputation appears to have allowed him to stretch the limits of what a commissioning organization might expect. He divides his book into two parts. The first part offers a chronological history, and the second explores key themes such as brands, human resources, and corporate culture, which are obviously seen as replicable and envisaged as a cumulative contribution to a thematic totality (cf. Jones \& Zeitlin, 2008).

As a by-product of his commissioned history, Jones's (2002) article on Unilever's subsidiaries in the United States (1945-1980) addresses their poor performance in relation to theories of multinational enterprise. There is a discernible norrative in the article, and as an accomplished historian with the benefit of temporal distance, Jones is able to reveal information that actors at the time were not aware of. However, even in the context of a theoretically informed article-and presumably with Jones freed from the constraints of his commission-there is no discussion of methods such as we would expect in organization theory. Even though Jones "draws extensively on the confidential business records" held by Unilever and claims to provide "rich new empirical evidence" on "the functioning of multinationals" (2002: 438, 478), with copious citations to internal committee minutes, memos, and reports, there is no dedicated discussion of sources.

While Jones deliberately stretched the constraints of narrative, Cheape (1988) was distracted from the conventional concerns of corporate history while researching his commissioned history 
of Norton, the American manufacturer of grinding wheels and abrasives (Cheape, 1985). His discovery of "unusual inside data" in the archives concerning the manager of Norton's German subsidiary from 1937 to 1959 prompted Cheape to explore the historiography of relations between business and the Third Reich between 1933 and 1945. Although Cheape's (1988) article does not have a recognizable methods section, it does include a brief account of the author's approach to source criticism through on intertemporal comparison of letters and reports written in Germany before 1942 and those produced for the manager's denazification hearings in 1946. Cheape realized the significance of his find in the archives from his awareness of the historical context and historiographical debate over the role of business in the Third Reich (see e.g. Nicosia \& Huener, 2004). Business schools and organization theorists have been criticized by historians for ignoring this particular debate (Berghahn, 2004: 139).

Corporate history demonstrates, therefore, the difficulty of reconciling our epistemological dualisms. Jones's (2002) move toward replicable thematic analysis is presented as if it is the only alternative to a common-sense founder-centered narrative. But thematic analysis tends to suppress historiographical debate, such as that over the role of business in the Third Reich, or the epistemological significance of contingent finds in the archives, such as Cheape's (1988). Organization theorists might suspect that commissioned corporate history lacks balance, and there is obviously an ideological bias in favor of particular types of academic historian, such as economists who see entrepreneurs as central to economic progress (Church, 1996). It should be noted, however, that many well-known corporate histories were not commissioned or authorized and only use sources in the public domain (e.g., Delamarter, 1986; Pendergrast, 2000). But in terms of historical theory (e.g., Novick, 1988; White, 1987), it can be argued that the ideological content of corporate history is contained in its objectivist form and founder-centered emplotment, which would be compromised by any hint of distortion or lack of independence. The content of the form of corporate history is inimical to explicit theoretical considerations of historical epistemology.

We can see from the discussion above that the word "objectivity" tends to be used as a polemic device, with little analysis of its meaning (Megill, 2007: 112). We tend to agree that judging whether a work of history is objective or not is "an empty observation" (Novick, 1988: 6). We can, of course, observe whether a history puts its evidence "on the table" by following the rules of verification, as do all of the corporate histories we have cited, and then assess whether the sources cited are compatible with the emplotment. Whether or not holism and objectivism originate from commissioning, they are pervasive in narrative corporate history, most of which is not commissioned. The sheer volume of corporate history, in books and academic articles, makes it appear as if only a particular kind of narrative can be constructed from organizational archives, one that is of relatively little interest for organization theorists except as an object of narrative analysis. In order to dispel that impression, we need to identify and assess alternative strategies for using and explaining the abundant sources available in organizational archives.

\section{Analytically Structured History}

On entering an organizational archive, organization theorists confront a choice of "whether to theorize processes within a narrative or within a generalizing, analytic schema" (Whipp \& Clark, 1986: 17-18). Instead of lapsing into either a common-sense founder-centered narrative or an analysis purged of narrative, we propose that it is possible to situate historical research and writing "on the bridge between narrative and analytic schemas" (Whipp \& Clark, 1986: 17-18). A narrative can be conceptualized as analytically structured history prior to entering an archive. For example, from a "structure-event-structure perspective," the periodization is derived from the sources, rather than imposed from an external historical context, and events in an organization constitute the turning points between one period and the next, "when novel elements are introduced and subsequently institutionalized in the new structure" (Whipp \& Clork, 1986: 19).

As a classic narrative account of organizations derived from primary documentary sources, Chandler's (1962) Strategy and Structure can be seen as an exemplar of analytically structured history, and it remains one of the best starting points for understanding historical re- 
search in organization theory (Kipping \& Üsdiken, 2008: 113). Chandler's historical narratives are in no sense holistic corporate histories; they are instead highly focused and based on a careful selection of sources. Nevertheless, his narratives have the literary quality expected from a well-written corporate history, with an eclectic range of sources marshaled to construct a seamless and satisfying narrative and with a large number of actors named (Stinchcombe, 1990: 109). Although Chandler was no less objectivist than most corporate historians, Strategy and Structure represents an important break with corporate history because named corporate entities are subordinate to concepts.

According to Stinchcombe, if Chandler had submitted an article on the multidivisional structure to a leading journal in management and organization theory, "a page or two about the histories of Du Point, General Motors, Jersey Standard, and Sears might have been in the original draft as motivation, to be cut by the editors as not science but anecdote" (1990: 104). But this dismissal of Chandler's historical narratives assumes that it was obvious what strategy and structure meant before Chandler provided historical illustrations for them. An interesting historiographical question is whether it was the extended descriptions in Chandler's historical narratives that provided us with the enduring definitions of strategy and structure. We maintain that Chandler's narratives established the causal link between strategy and structure, and his long descriptive sections were not anecdotal but necessary for constructing these concepts. Chandler's narratives are thus emplotted by the analytic constructs of strategy and structure.

Chandler himself gave few clues as to his own theory of history or actual working methods. We have to rely on commentators for an exposition of his functionalist theory of history (Mayhew, 2009; Roy, 1990; Stinchcombe, 1990) and his use of sources (McKenna, 2006), as well as a close reading of the text itself. Chandler's (1962) chapter on General Motors (GM) is probably the best illustration of analytically structured history and is the focus for later historiographical debate (Freeland, 1996). Chandler used a range of narrative or secondary sources to recount GM's strategy of diversification up to 1920: "annual and other corporation reports, government documents, magazine articles, and the few pertinent business histories and biographies" (1962: viii). He accepted that changes in strategy can be gleaned from a general survey of these sources but maintained that "only a study of a company's internal business documents and letters can accurately reveal the details of structural reorganization" (1962: 380). In other words, Chandler only used primary social documents, such as minutes from GM's board of directors' meetings, to narrate an event-the structural reorganization of GM during 1920 and 1921.

Freeland's (1996) analytically structured history starts where Chandler's narrative leaves off, with the adoption of the multidivisional structure by GM in 1921. Freeland (1996: 497) argues that for most of the forty-year period beginning in 1924, GM did not have "a textbook M-form," and he highlights the differences in operation of what was ostensibly the same structure in a series of defined periods. Unlike Chandler, however, Freeland (1996: 493) outlines his theoretical orientation at length and gives a brief account of his methods, highlighting his use of newly available archival documentary sources, especially the correspondence between Alfred Sloan and the owners of GM. He addresses the problem of bias in accounts by executives but argues that their consistency over time is an indication of reliability. Freeland presents a sparser linear narrative for GM over a longer period than Chandler by narrating the organizational structure as a "quasi-character" at the expense of named actors or events. Freeland retains narrativization, but by focusing on the clearly stated periods between the turning points, he places much less emphasis than Chandler on a narrative account of events.

Analytically structured history thus uses analytic constructs-such as "strategy" and "structure"-to search archival sources, enabling the construction of a narrative of structures and events that may not even have been perceived as such by actors at the time. Hence, although analytically structured history retains norrative as the main form of explanation, it is driven by concepts, events, and causation, whereas corporate history focuses on a corporate entity and leading individuals. Analytically structured history may draw on secondary sources and narrative texts, but that is not the same as a reworking or an analysis of the narratives already contained within those sources. Analytically 
structured history is therefore a form of norrative construction from organizational archives, not merely the reconstitution of a narrative from narrative analysis. We suggest that historically oriented theories of organization, such as new institutionalism, institutional work, and institutional logics, are amenable to analytically structured history, with the construction of historical events from organizational archives providing a potential focus for actors and agency. Self-consciously emplotted analytically structured history is also more defensible than corporate history against objections to narrative construction.

\section{Serial History}

For historical theorists who focus on the epistemological status of narrative, serial history represents a standard alternative to narrative history (Clark, 2004: 121; cf. Langley, 1999: 691). Serial history is predicated on finding a series of "repeatable facts" (Ricoeur, 1990: 106) that can be analyzed using replicable techniques, usually in a predefined set of chronologically continuous sources, if not an actual quantitative data set. As the preferred strategy for history in organization studies, serial history constantly threatens to eclipse narrative-to use Ricoeur's (1990) term - through continual advances in such methods as event history analysis. However, while serial history does not necessarily preclude analysis of primary social documents derived from organizational archives, such as minutes of meetings, these sources would require laborious processing in order to construct "repeatable facts" that could be usable as data. Secondary data sets may occasionally be found in organizational archives (Payne, Finch, \& Tremble, 2003), but research using such archival data makes no real claim to be historical in our terms (e.g., Dokko, Wilk, \& Rothbard, 2009). It is hardly surprising, therefore, that we have found little or no serial history that attempts, in our epistemological terms, to explain the evidence found in a particular organizational archive. Hence, these rich sources, which are a mainstay for corporate history and analytically structured history, remain largely unexplained by the dominant historical strategy in organization theory.

Serial history mainly focuses on organizational fields or populations, rather than individual organizations. Occasionally, as Chuang and
Baum (2003) have demonstrated, data covering the "life histories" of multiple organizations can be constructed from the archive of an association or a licensing or regulatory organization, as opposed to the archives of the organizations that are the object of investigation. Chuang and Baum compiled data on 557 nursing homes operating in Ontario between 1971 and 1996 from "two archival sources: the Ontario Ministry of Health $(\mathrm{MOH})$ licensing records and the Ontario Hospitals' Association (OHA) Directory" (2003: 42). They used their data on nursing homes to test a series of hypotheses regarding the adoption of common names for components of multiunit chains. What is interesting from our perspective is that although Chuang and Baum's serial history represents a valuable contribution to the growing literature on organizational name changes, the subordination of narrative to analysis is such that there is no discussion of the history of naming for nursery homes, and the actual names are not revealed. We are only told whether nursing homes shared their names with others that identified them as part of a chain. Finally, Chuang and Baum appear to have chosen the period 1971 to 1996 for the availability of chronologically continuous archival sources rather than for any historiographical significance.

For a more interpretive form of serial history, "content analysis of archival documents composed of qualitative textual data" (Sonpar \& Golden-Biddle, 2008: 795) can be applied to norrative sources in an organizational archive. As an example of such serial history, Anteby and Molnar's (2012) research stands out for its content analysis of 309 internal bulletins from the French aeronautics firm Snecma, covering the nearly 50 years from 1953 to 1999. Anteby and Molnar use their data to show how there was a "structural omission" of contradictory elements from the firm's official historical record. This demonstrates how corporate cultural communications, such as internal bulletins or company magazines, represent primary narrative sources that are amenable to quantitative narrative analysis in serial history. These sources are part of an organizational archive since they are clearly generated by the organization itself. As Anteby and Molnar (2012: 521) point out, the internal bulletins they analyzed can reliably be taken to represent an official view because they were "approved by Snecma's top management," 
which turns the alleged weakness of such sources into a strength. It is also worth noting that Anteby and Molnar's historical research represents a novel contribution from organization theory to the field of collective memory studies, in which both serial history and organizational history have been neglected (Rowlinson, Booth, Clark, Delahaye, \& Procter, 2010; cf. Olick, Vinitzky-Seroussi, \& Levy, 2011).

\section{Ethnographic History}

For our final strategy, ethnographic history, we note initially how organizational ethnography has been defined by three criteria: (1) ethnographic methods, with a requirement for observation and "talking to people"; (2) a narrative form of writing; and (3) an "ethnographic sensibility that would convince the reader of the trustworthiness of the author" (Yanow \& Geuijen, 2009: 254). The emphasis on fieldwork and the construction of data for generating theory reflect the need to gain legitimacy in organization studies (Zickar \& Carter, 2010). Nevertheless, we can deploy the criteria used to define organizational ethnography to consider its similarities to and differences from ethnographic history.

Historical researchers obviously cannot be present, with notebooks, tape recorders, and cameras, at the events they describe, but occasionally they discover a cache of sources from witnesses that can "tell us what it was like to be there" (Stone, 1979: 14). More important, historians have interpreted cultural anthropology, and especially Geertz's (1973) notion of "thick description," to mean that culture can be understood as a text (Gunn, 2006: 63), with an emphasis on how texts can be read, rather than as a method for constructing texts. Van Maanen (1988: 76) has claimed that ethnographers have to construct their texts from the field, whereas the texts used by historians and literary critics "come prepackaged." Even if it were true that historical sources came prepackaged, and anyone who has ever worked on an organizational archive will know that they do not, it is not clear why the interpretation of cultures should privilege texts constructed by ethnographers. Besides, historical researchers often enter into relationships with regard to their sources comparable to those of an ethnographer entering the field, especially when the documents are held in the "living archive" of an extant organi- zation (Hill, 1993: 54; Howell \& Prevenier, 2001), so the contrast with fieldwork may be overdone.

In fact, ethnographic history-also known as ethnohistory, anthropological history (Green \& Troup, 1999), or microhistory (Clark, 2004: 7579) - is now widely accepted by historians, reflecting the rise of cultural history (Megill, 2007: 203). The most celebrated example of ethnographic history is the international bestseller Montaillou, in which Le Roy Ladurie (1980) used the records of the Inquisition to interpret the culture of medieval peasants (see Sewell, 2005: 69, and Stone, 1979). As an example of reading sources against the grain, Le Roy Ladurie was not so much interested in the Inquisition, or the nature of the peasants' heresy, but, rather, in using the Inquisition's records as if they were ethnographic field notes recording peasant culture.

If we accept that ethnography consists of $\alpha$ perspective as much as a method, then we can see that organizational archives contain sources that can be read as texts for an interpretation of culture. But in comparison with corporate history, ethnographic history requires a selfconsciously "angular" theoretical perspective (Megill, 2007: 110-111). Childs (2002), for example, adopts a Bakhtinian (Bakhtin, 1968) perspective in his account of a gold mine operated by the British-owned St. John d'el Rey Mining Company in the Brazilian tropics during the nineteenth century. In this account Childs focuses on a particular ritualized display of power, in which "on Sundays nearly 1,500 slaves from the mine, separated by sex, lined up in columns in front of the Casa Grande (big house) for a ceremony called the Revista (review)" (2002: 43). Like an ethnographer, Childs interprets the meaning of this ritual as a way to explore broader social relations between masters and slaves. Following Bakhtin's emphasis on the carnivalesque in early modern Europe (Gunn, 2006: 68), Childs is alert to the pride and shame of the slaves and in particular to any opportunity they took to ridicule their masters.

As a historion, Childs is interested in the historical legacies of slavery and racism in shaping the modern world, which has been largely neglected in organization theory (Cooke, 2003). The "industrial slavery" at the gold mine in Brazil involved a seemingly modern organization of labor, with up to 1,700 slaves, most of them rented from other slave owners, "working at nu- 
merous individualized tasks as miners, borers, strikers, surface laborers, carpenters or masons, but rarely in the large work gangs common to plantation slavery" (Childs, 2002: 49; cf. Crane, 2013). Childs' primary sources are from the St. John d'el Rey Mining Company Archive, held by the University of Texas at Austin, which Childs reads against the grain. In response to criticism in the British press for the company's use of slave labor, long after the abolition of slavery by Great Britain in 1833, the directors of the St. John Company commissioned an "independent" report on the condition of "the Negroes." The fiftypage Circular to the Proprietors of the St. John d'el Rey Mining Company was sent out to stockholders in 1850, assuring them of the "humane and generous ... measures already adopted ... to render them [the slaves] as contented and happy as men can be expected to be, whose lot is to earn their bread by the sweat of their brow" (quoted in Childs, 2002: 48). The narrative text of the Circular is one of Childs' main primary sources, along with the company's annual reports and social documents, such as the minutes of board meetings. But Childs' angular theoretical perspective is nothing like an objectivist narrative corporate history explaining the longevity or performance of a multinational mining company.

As an ethnographic history, McKinlay's (2002) analysis of clerks' careers in the Bank of Scotland before the First World War relies on documentary sources found in an organizational archive. But whereas Childs follows Bakhtin, McKinlay follows Foucault (1977) into the archives. McKinlay points out that his reading of the modern banking career is very different from a "conventional" or corporate history. In his description of how the clerks were disciplined by the emerging concept of a career, McKinlay's main sources are staff ledgers, in which annual appraisals were recorded. While searching the bank ledgers, however, McKinlay found hundreds of drawings hidden in a secret "Ledger 99," produced by a clerk, Robert Shirlaw, who worked for the bank from 1899 (aged 16) until his death in 1930. A talented cartoonist, Shirlaw caricatured the bank's employees and their work situations, regularly depicting the bank's manager as Napoleon (McKinlay, 2002: 603, Figure 1). McKinlay's analysis brings the clerks' occupational world to life with a series of microstories pieced together from ledgers that illustrate, for example, the bank's tight surveillance and control of behavior.

This returns us to the definition of organizational ethnography as narrative. Organizational ethnographers are understandably anxious not to be constrained by the "succinct textual form" that prevails in organization studies, and, therefore, they emphasize the narrative aspect of their own writing (Yanow \& Geuijen, 2009). But in the context of history, and in comparison to corporate history, ethnographic history represents a conscious refusal to impose a plot in a move toward a "non-event worthy history" (Veyne, 1984: 54), one that is wary of metanarratives and universalizing theories. With their angular theoretical perspectives (Megill, 2007), both Childs and McKinlay distance themselves from the metanarratives that emphasize functional or economic logic in the demise of slavery and the rise of modern careers. Childs' account in particular is thematically structured, exploring, for example, the role of overtime and religion in the slaves' Sunday routines. Routines and rituals of power are presented as relatively constant within an extended period, starting with the commencement of operations by the St. John Company in the 1830s and ending with the emancipation of the slaves during the 1870s (Childs, 2002: 62). Even if written as a microstory, ethnographic history tends to avoid the implication that the events recounted are "historical" in the sense of changing the course of history.

Like much historiography, then, ethnographic history owes a lot to the serendipity of finding sources (Ginzburg, 1992/1976: xi; Jordanova, 2006: 37). But ethnographic researchers recognize the significance of the intriguing sources they find in organizational archives because they know what kind of sources they are looking for (McKinlay, 2013). Researchers writing a corporate history would not normally look for such sources and, even if they found them, would probably discard them as a distraction. Recognizing the significance of such finds in on archive therefore requires an "ethnographic sensibility" and on "angular" theoretical perspective.

\section{DISCUSSION}

We have demonstrated that corporate history, analytically structured history, serial history, and ethnographic history are as different from one another as are other strategies for research 
and writing in organization studies. Therefore, if history matters for organization theory, it makes no sense to try to find a unified ontological or epistemological foundation, let alone a unitary "historical method" for organizational history. The epistemological dualisms in explanation, evidence, and temporality that we set out in the first part of this article highlight the similarities and differences between alternative strategies for organizational history (see Table 3). We have identified these strategies with the intention of demonstrating that serial history, with its replicable procedures for constructing data, is not the only alternative to narrative corporate history. Ethnographic history also represents an alternative to the narration of historiographical events in response to the impositionalist objection to narrative. And analytically structured history offers the possibility of constructing historical narratives using theories of organization that can be defended against social scientific objections to narrative construction.

We have made the case that organizational archives are not merely an underutilized source of data; in historical terms they also represent largely unexplained evidence. The sheer volume of corporate history, whether commissioned or not, suggests that many organizations consider this evidence worthy of retention and explanation. However, for the epistemological reasons we have given, we do not believe that we should leave it to corporate history to explain the evidence in organizational archives. We would like to promote greater use of organizational archives with alternative strategies for research and writing. This will require epistemological reflexivity in order to counter reservations regarding the use of organizational archives in organization theory.

We should point out that much material from organizational archives is in the public domain, as was the case for several of our exemplars
(Anteby \& Molnar, 2012; Chandler, 1962; Childs, 2002; Freeland, 1996), which means that researchers do not need special permission from an organization before consulting the archives. However, having gained access to an organizational archive, organization theorists then need to know what to look for. Corporate history tends to follow the narrative embedded in the "conventional hierarchy" of an organizational archive (McKinlay, 2013), which is partly why corporate historians are unable or unwilling to write up their theory and methods. Analytically structured history and ethnographic history, though, require a degree of epistemological reflexivity, as is expected from interpretive organization theorists (Alvesson \& Sköldberg, 2009), and which our epistemological dualisms facilitate.

An understanding of historical theory is also desirable if organization theorists are to become more sophisticated consumers of historiography, even if they do not intend to conduct archival historical research themselves. It seems unlikely that an organization theorist would be commissioned to write a corporate history; nevertheless, corporate histories represent valuable secondary sources, which offer vicarious access to a wealth of primary sources. When we read corporate histories, therefore, we need an appreciation of how they are emplotted by their objectivism and founder-centered narratives.

Epistemological reflexivity is necessary because, like most nonhistorians who rely on secondary sources, such as corporate histories, or prepackaged primary sources (Jordanova, 2006: 38; O'Sullivan \& Graham, 2010), organization theorists often use historiography as if it represents an unproblematic "historical record." Many of the best known histories in organization studies, such as The Visible Hand (Chandler, 1977) or Scale and Scope (Chandler, 1990), are, in fact, masterpieces of historiographical synthesis, which rely mainly on secondary

TABLE 3

Examples of Research Strategies for Organizational History

\begin{tabular}{lllll}
\hline & \multicolumn{3}{c}{ Strategies } \\
\cline { 2 - 5 } Dualisms & Corporate History & Analytically Structured History & Serial History & Ethnographic History \\
\hline Explanation & Narrative (corporate entity) & Narrative (conceptual construct) & Analysis & Analysis \\
Evidence & Sources & Sources & Data & Sources \\
Temporality & Periodization & Periodization & Chronology & Periodization \\
\hline
\end{tabular}


sources, such as corporate histories (Kobrak \& Schneider, 2011). We cannot expect organizational researchers to refer constantly to their historical writing as an interpretation of commentaries on the traces of past events. However, if they did so more often, this would lead to a greater appreciation of the craft skills required to interpret primary sources.

A more fundamental concern is that organization theorists, compared to theorists from other fields, have little to say about the significance of historical events for understanding our present and future. Take, for example, Sofsky's "thick description" of "power in the concentration camp" in The Order of Terror (1999), which we would characterize as an ethnographic history of an organizational form. Sofsky makes no mention of organization theory, because organization theory has little to offer by way of research concerning concentration camps (Lammers, 1995). It would be unseemly to ask how studying concentration camps could advance organization theory (Clegg, 2002), but if understanding the past is central to our historical human condition (Ricoeur, 2004), then we should ask how organization theory can help to explain singular historical events or organizational forms. In other words, it may be selfdefeating to insist that organization theory is synonymous with the relentless subordination of idiographic history to nomothetic social science.

A clear conclusion from our epistemological dualisms and alternative strategies is that there is no prospect of a unified field of organizational history. History is no less fragmented than organization theory, and historical theorists (e.g., Megill, 2007) are no less suspicious of any attempt to impose paradigm consensus than organization theorists (Van Maanen, 1995). Nevertheless, if we are to realize the potential for a plurality of historical perspectives in organization theory, we should consider the prospects for dialogue with historians, as historical sociologists such as Sewell (2005) have done. In order to facilitate such a dialogue, we should try to recognize what it is that organization theorists know or need to know, and what it is that historians know or need to know. Whereas organization theorists need to understand theory and methods, historions need to know their historical contexts and sources. Therefore, we cannot regard historians simply as untrained theorists awaiting analysis to replace their narratives or replicable methods for constructing chronological datasets.
We are aware that historians tend to dismiss theoretical interventions from anyone who has not "dirtied their hand in the archive" (Fulbrook, 2002: 25), so we should stress that our strategies are partly derived from reflection on our own experience of theoretically informed historical research and writing (Decker, 2010; Hassard, 2012; Rowlinson, 1988). Even though we would like to encourage organizational researchers to venture into organizational archives, we recognize that most of us are restricted to examining the relatively recent past by our preferred methods, as well as by our limited knowledge of historical contexts and sources. Only a few organization theorists have looked at organizations before the nineteenth century (Kieser, 1987, 1989; Newton, 2004; Ruef \& Harness, 2009), and the further back we go, the more dependent we are on historiography and an appreciation of how historians work. Historical sociologists looking at the Reformation (Wuthnow, 1989), for example, know they need an appreciation of how historians work with sources if they are going to read and theorize from historiography.

Finally, we should note that historians now seem more willing to articulate and share their knowledge of the craft skills required in organizational archives (see Adorisio \& Mutch, 2013, and Bucheli \& Wadhwani, 2014). McKenna's (2006) revelations of Chandler's research in the archives of General Motors, along with McKinlay's (2013) intriguing account of how he traced the books and documents ordered by Foucault in the Biblioteque Nationale, tell us more than Chandler or Foucault themselves did about their working methods. However, before we decide to follow Chandler or Foucault into organizational archives, we need to know which of their very different kinds of history best reflect our own theoretical stance, and for that we need more than a methodological toolkit. We have signposted some of the philosophers of history and historical theorists who con help us to discover our own reflexive theoretical stance in relation to history. Our exposition of the epistemological dualisms of explanation, evidence, and temporality, as well as our identification of corporate history, analytically structured history, serial history, and ethnographic history as alternative strategies for research and writing organizational history, represents a contribution toward mutual understanding among organization theorists, historical theorists, and practicing historions. 


\section{REFERENCES}

Abbott, A. 1992. From causes to events: Notes on narrative positivism. Sociological Methods and Research, 20: 428455 .

Abbott, A. 1997. Of time and space: The contemporary relevance of the Chicago School. Social Forces, 75: 11491182.

Abbott, A. 2001. Time matters: On theory and method. Chicago: University of Chicago Press.

Adorisio, A. L. M., \& Mutch, A. 2013. In search of historical methods. Management \& Organizational History, 8(Special Issue): 105-110.

Aldrich, H. E. 1999. Organizations evolving. Thousand Oaks, CA: Sage.

Alvesson, M., \& Sköldberg, K. 2009. Reflexive methodology: New vistas for qualitative research (2nd ed.). Los Angeles and London: Sage.

Anteby, M., \& Molnar, V. 2012. Collective memory meets organizational identity: Remembering to forget in a firm's rhetorical history. Academy of Management Journal, 55: 515-540.

Arndt, M., \& Bigelow, B. 2005. Professionalizing and masculinizing a female occupation: The reconceptualization of hospital administration in the early 1900s. Administrative Science Quarterly, 50: 233-261.

Bakhtin, M. M. 1968. Rabelais and his world. Cambridge, MA: MIT Press.

Barrett, F. J., \& Srivasta, S. 1991. History as mode of inquiry in organizational life: A role for human cosmogeny. Human Relations, 44: 231-254.

Barry, D., \& Elmes, M. 1997. Strategy retold: Toward a narrative view of strategic discourse. Academy of Management Review, 22: 429-452.

Bates, R. H., Greif, A., Levi, M., Rosenthal, J. L., \& Weingast, B. R. (Eds.). 1998. Analytic narratives. Princeton, NJ: Princeton University Press.

Bedeian, A. G. 1997. Of fiction and fraud: A comment on Barry and Elmes' article. Academy of Management Review, 22: 840-842.

Berghahn, V. R. 2004. Writing the history of business in the Third Reich: Past achievements and future directions. In F. R. Nicosia \& J. Nuener (Eds.) Business and industry in Nazi Germany: 129-148. Oxford: Berghahn.

Boje, D. M. 1995. Stories of the storytelling organization-A postmodern analysis of Disney as Tamara-land. Academy of Management Journal, 38: 997-1035.

Boje, D. M. 2008. Storytelling organizations. Thousand Oaks, CA: Sage.

Booth, C., \& Rowlinson, M. 2006. Management and organizational history: Prospects. Management \& Organizational History, 1: 5-30.

Brown, K. G., \& Hörtel, C. E. J. 2011. Introduction: History matters. Academy of Management Learning \& Education, 10: 351-352.

Bucheli, M., \& Wadhwani, R. D. (Eds.). 2014. Organizations in time: History, theory, methods. New York: Oxford University Press.

Callinicos, A. 1995. Theories and narratives: Reflections on the philosophy of history. Cambridge: Polity Press.

Campion, F. D. 1987. How to handle the corporate history. Public Relations Journal, 43: 31-32.

Carpenter, D. 2000. Analytic narratives. Social Science History, 24: 653-667.

Carr, D. 1998. Narrative and the real world: An argument for continuity. In B. Fay, P. Pomper, \& R. T. Vann (Eds.), History and theory: Contemporary readings: 137-171. Malden, MA: Blackwell.

Chandler, A. D. J. 1962. Strategy and structure: Chapters in the history of industrial enterprise. Cambridge, MA: MIT Press.

Chandler, A. D. J. 1977. The visible hand: The managerial revolution in American business. Cambridge, MA: Belknap Press of Harvard University Press.

Chandler, A. D. J. 1990. Scale and scope: The dynamics of industrial capitalism. Cambridge, MA: Harvard University Press.

Cheape, C. W. 1985. Family firm to modern multinational: Norton Company, a New England enterprise. Cambridge, MA: Harvard University Press.

Cheape, C. W. 1988. Not politicians but sound businessmen-Norton Company and the Third-Reich. Business History Review, 62: 444-466.

Childs, M. D. 2002. Master-slave rituals of power at a gold mine in nineteenth-century Brazil. History Workshop Journal, 53: 43-72.

Chuang, Y. T., \& Baum, J. A. C. 2003. It's all in the name: Failure-induced learning by multiunit chains. Administrative Science Quarterly, 48: 33-59.

Church, R. 1996. Deconstructing Nuffield: The evolution of managerial culture in the British motor industry. Economic History Review, 49: 561-583.

Clark, E. A. 2004. History, theory, text: Historians and the linguistic turn. Cambridge, MA: Harvard University Press.

Clark, P., \& Rowlinson, M. 2004. The treatment of history in organisation studies: Towards an "historic turn"? Business History, 46: 331-352.

Clegg, S. R. 2002. "Lives in the balance": A comment on Hinings and Greenwood's disconnects and consequences in organization theory? Administrative Science Quarterly, 47: 428-44l.

Cobley, P. 2001. Narrative. London: Routledge.

Coleman, D. 1987. The uses and abuses of business history. Business History, 29: 141-156.

Cooke, B. 2003. The denial of slavery in management studies. Journal of Management Studies, 40: 1895-1918.

Crane, A. 2013. Modern slavery as a management practice: Exploring the conditions and capabilities for human exploitation. Academy of Management Review, 38: $49-69$. 
Cummings, S., \& Bridgman, T. 2011. The relevant past: Why the history of management should be critical of our future. Academy of Management Learning \& Education, 10: 77-93.

Czarniawska, B. 1999. Writing management: Organization theory as a literary genre. Oxford: Oxford University Press.

de Certeau, M. 1988. The writing of history. New York: Columbia University Press.

Decker, S. 2010. Postcolonial transitions in Africa: Decolonization in West Africa and present day South Africa. Journal of Management Studies, 47: 791-813.

Decker, S. 2013. The silence of the archives: Business history, post-colonialism and archival ethnography. Management \& Organizational History, 8: 155-173.

Delamarter, R. T. 1986. Big Blue: IBM's use and abuse of power. London: Macmillan.

Delbridge, R., \& Fiss, P. 2013. Editors' comments: Styles of theorizing and the social organization of knowledge. Academy of Management Review, 38: -325-331.

Dellheim, C. 1986. Business in time: The historian and corporate culture. Public Historian, 8(2): 9-22.

Denrell, J., \& Kovacs, B. 2008. Selective sampling of empirical settings in organizational studies. Administrative Science Quarterly, 53: 109-144.

Denzin, N. K., \& Lincoln, Y. S. 2000. Strategies of inquiry. In N. K. Denzin \& Y. S. Lincoln (Eds.), Handbook of qualitative research (2nd ed.): 367-378. Thousand Oaks, CA: Sage.

DiMaggio, P. J. 1995. Comments on "What theory is not." Administrative Science Quarterly, 40: 39l-397.

Dokko, G., Wilk, S. L., \& Rothbard, N. P. 2009. Unpacking prior experience: How career history affects job performance. Organization Science, 20: 51-68.

Down, S. 2001. Knowledge sharing review-The use of history in business and management, and some implications for management learning. Management Learning, 32: 393-410.

Dray, W. H. 1986. Narrative versus analysis in history. In J. Margolis, M. Krausz, \& R. M. Burian (Eds.), Rationality, relativism, and the human sciences: $23-42$. Dordrecht and Boston: Nijhoff.

Eisenhardt, K. M. 1989. Building theories from case-study research. Academy of Management Review, 14: 532-550.

Eisenhardt, K. M., \& Graebner, M. E. 2007. Theory building from cases: Opportunities and challenges. Academy of Management Journal, 50: 25-32.

Evans, R. J. 1997. In defence of history. London. Granta.

Ferguson, N. 1998a. He who sups with the devil must use a long spoon-and bring a good agent. Times Higher Education, December 28: http://www.timeshighereducation. co.uk/features/he-who-sups-with-the-devil-must-use- $\alpha$ long-spoon-and-bring-a-good-agent/1 10455.article.

Ferguson, N. 1998b. The world's banker: The history of the house of Rothschild. London: Weidenfeld \& Nicolson.

Foucault, M. 1977. Discipline and punish: The birth of the prison. (Translated by A. Sheridan.) New York: Pantheon Books.

Freeland, R. F. 1996. The myth of the m-form? Governance, consent, and organizational change. American Journal of Sociology, 102: 483-526.

Fulbrook, M. 2002. Historical theory. London and New York: Routledge.

Gaddis, J. L. 2004. The landscape of history: How historians map the past. New York: Oxford University Press.

Geertz, C. 1973. The interpretation of cultures. New York: Basic Books.

Giddens, A. 1984. The constitution of society: Outline of the theory of structuration. Cambridge: Polity Press.

Ginzburg, C. 1992. (First published in 1976.) The cheese and the worms: The cosmos of a sixteeenth-century miller. (Translated by J. Tedeschi \& A. Tedeschi.) Baltimore: Johns Hopkins University Press.

Golden, B. R. 1997. Further remarks on retrospective accounts in organizational and strategic management research. Academy of Management Journal, 40: 1243-1252.

Goodman, R. S., \& Kruger, E. J. 1988. Data dredging or legitimate research method-Historiography and its potential for management research. Academy of Management Review, 13: 315-325.

Grafton, A. 1997. The footnote: $\bar{A}$ curious history. Boston: Harvard University Press.

Green, A., \& Troup, K. 1999. The houses of history: A critical reader in twentieth-century history and theory. Manchester, UK: Manchester University Press.

Gunn, S. 2006. History and cultural theory. Harlow, UK: Pearson Education.

Hannan, M. T., \& Freeman, J. 1989. Organizational ecology. Cambridge, MA: Harvard University Press.

Hardy, C., \& Maguire, S. 2010. Discourse, field-configuring events, and change in organizations and institutional fields: Narratives of DDT and the Stockholm convention. Academy of Management Journal, 53: 1365-1392.

Hassard, J. 2012. Rethinking the Hawthorne Studies: The Western Electric research in its social, political and historical context. Human Relations, 65: 1431-1461.

Haveman, H. A. 1993. Ghosts of managers past: Managerial succession and organizational mortality. Academy of Management Journal, 36: 864-881.

Hegel, G. W. F. 1956. The philosophy of history. (Translated by J. Sibree.) New York: Dover.

Hexter, J. H. 1998. The rhetoric of history. In B. Fay, P. Pomper, \& R. T. Vann (Eds.), History and theory: Contemporary readings: 59-68. Malden, MA: Blackwell.

Hill, M. R. 1993. Archival strategies and techniques. Newbury Park, CA: Sage.

Howell, M., \& Prevenier, W. 2001. From reliable sources: An introduction to historical methods. Ithaca, NY: Cornell University Press.

Jarzabkowski, P., Matthiesen, J., \& Van de Ven, A. H. 2009. Doing which work? A proctice approach to institutional 
pluralism. In T. B. Lawrence, R. Suddaby, \& B. Leca (Eds.), Institutional work: Actors and agency in institutional studies of organization: 284-316. Cambridge: Cambridge University Press.

Jones, G. 2002. Control, performance, and knowledge transfers in large multinationals: Unilever in the United States, 1945-1980. Business History Review, 76: 435-478.

Jones, G. 2005. Renewing Unilever: Transformation and tradition. Oxford: Oxford University Press.

Jones, G. 2012. The future of business history. Scandinavian Economic History Review, 60: 225-235.

Jones, G., \& Sluyterman, K. E. 2003. British and Dutch business history. In G. Jones \& F. Amatori (Eds.), Business history around the world: 111-145. Cambridge: Cambridge University Press.

Jones, G., \& Zeitlin, J. (Eds.). 2008. The Oxford handbook of business history. Oxford: Oxford University Press.

Jordanova, L. 2006. History in practice (2nd ed.). London: Hodder Education.

Kieser, A. 1987. From asceticism to administration of wealth-Medieval monasteries and the pitfalls of rationalization. Organization Studies, 8: 103-123.

Kieser, A. 1989. Organizational, institutional, and societal evolution-Medieval craft guilds and the genesis of formal organizations. Administrative Science Quarterly, 34: 540-564.

Kieser, A. 1994. Crossroads-Why organization theory needs historical analyses-and how these should be performed. Organization Science, 5: 608-620.

Kipping, M., \& Üsdiken, B. 2008. Business history and management studies. In G. Jones \& J. Zeitlin (Ed.), The Oxford handbook of business history: 96-119. Oxford: Oxford University Press.

Kobrak, C., \& Schneider, A. 2011. Varieties of business history: Subject and methods for the twenty-first century. Business History, 53: 401-424.

Kuhn, T. S. 1970. The structure of scientific revolutions (2nd enlarged ed.). Chicago: University of Chicago Press.

Lammers, C. J. 1995. The organization of mass murder. Organization Studies, 16: 139-156.

Langley, A. 1999. Strategies for theorizing from process data. Academy of Management Review, 24: 691-710.

Lawrence, B. S. 1984. Historical perspective-Using the past to study the present. Academy of Management Review, 9: 307-312.

Lawrence, T. B., \& Suddaby, R. 2006. Institutions and institutional work. In S. R. Clegg, C. Hardy, T. B. Lawrence, \& W. R. Nord (Eds.), The Sage handbook of organization studies (2nd ed.): 215-254. London: Sage.

Lawrence, T. B., Suddaby, R., \& Leca, B. 2009. Introduction: Theorizing and studying institutional work. In T. B. Lawrence, R. Suddaby, \& B. Leca (Eds.), Institutional work: Actors and agency in institutional studies of organizations: 1-27. Cambridge: Cambridge University Press.

Le Roy Ladurie, E. 1980. Montaillou: Cathars and Catholics in a French village 1294-1324. (Translated by B. Bray.). London: Penguin.

Linde, C. 2009. Working the past: Narratives and institutional memory. New York: Oxford University Press.

Lorenz, C. 2011. History and theory. In A. Schneider, D. Woolf, \& I. Hesketh (Eds.), The Oxford history of historical writing. Volume 5: Historical writing since 1945: 13-35. Oxford: Oxford University Press.

MacCulloch, D. 2010. A history of Christianity. New York: Penguin.

Madansky, A. 2008. Teaching history in business schools: An outsider's view. Academy of Management Learning \& Education, 7: 553-562.

Martin, J. 1992. Cultures in organizations: Three perspectives. Oxford: Oxford University Press.

Martin, J., Sitkin, S. B., \& Boehm, M. 1985. Founders and the elusiveness of a cultural legacy. In P. J. Frost, L. F. Moore, M. R. Louis, C. C. Lundberg, \& J. Martin (Eds.), Organizational culture: 99-124. London: Sage.

Mayhew, A. 2009. Narrating the rise of big business in the USA. New York: Routledge.

McDonald, T. J. (Ed.). 1996. The historic turn in the human sciences. Ann Arbor: University of Michigan Press.

McKenna, C. D. 2006. Writing the ghost-writer back in: Alfred Sloan, Alfred Chandler, John McDonald and the intellectual origins of corporate strategy. Management \& Organizational History, 1: 107-1261: 107-126.

McKinlay, A. 2002. "Dead selves": The birth of the modern career. Organization, 9: 595-614.

McKinlay, A. 2013. Following Foucault into the archives: Clerks, careers and cartoons. Management \& Organizational History, 8: 137-154.

Megill, A. 2005. Review of our knowledge of the past: A philosophy of historiography by Aviezer Tucker (2004). Journal of Indo-European Studies, 33: 453-461.

Megill, A. 2007. Historical knowledge, historical error: A contemporary guide to practice. Chicago and London: University of Chicago Press.

Mills, A. J. 2006. Sex, strategy and the stratosphere: Airlines and the gendering of organizational culture. Houndmills, Basingstoke, UK, and New York: Palgrave Macmillan.

Munslow, A. 2012. A history of history. New York: Routledge.

Neimark, M. K. 1992. The hidden dimensions of annual reports: Sixty years of conflict at General Motors. New York: Markus Wiener.

Newton, T. 2004. From Freemasons to the employee: Organization, history and subjectivity. Organization Studies, 25: 1363-1387.

Nicosia, F. R., \& Huener, J. (Eds.). 2004. Business and industry in Nazi Germany. New York: Berghahn.

Norman, A. P. 1998. Telling it like it was: Historical narratives on their own terms. In B. Fay, P. Pomper, \& R. T. Vann (Eds.), History and theory: Contemporary readings: 153171. Malden MA: Blackwell. 
Novick, P. 1988. That noble dream: The "objectivity question" and the American historical profession. New York: Cambridge University Press.

Olick, J. K., Vinitzky-Seroussi, V., \& Levy, D. (Eds.). 2011. The collective memory reader. New York: Oxford University Press.

O'Sullivan, M., \& Graham, M. B. W. 2010. Moving forward by looking backward: Business history and management studies. Journal of Management Studies, 47: 775-790.

Payne, S. C., Finch, J. F., \& Tremble, T. R. 2003. Validating surrogate measures of psychological constructs: The application of construct equivalence to archival data. Organizational Research Methods, 6: 363-382.

Pedriana, N. 2005. Rational choice, structural context, and increasing returns-A strategy for analytic norrative in historical sociology. Sociological Methods and Research, 33: 349-382.

Pendergrast, M. 2000. For God, country, and Coca-Cola: The definitive history of the great American soft drink and the company that makes it (2nd ed.). New York: Basic Books.

Pentland, B. T. 1999. Building process theory with narrative: From description to explanation. Academy of Management Review, 24: 711-724.

Pierson, P. 2004. Politics in time: History, institutions, and social analysis. Princeton, NJ: Princeton University Press.

Popper, K. 2002. (First published in 1957.) The poverty of historicism. London and New York: Routledge.

Prasad, A., \& Prasad, P. 2002. The coming of age of interpretive organizational research. Organizational Research Methods, 5: 4-11.

Ricoeur, P. 1990. Time and narrative: Volume 1. (Translated by K. McLaughlin \& D. Pellauer.) Chicago: University of Chicago Press.

Ricoeur, P. 2004. Memory, history, forgetting. (Translated by K. Blamey \& D. Pellauer.) Chicago: University of Chicago Press.

Riessman, C. K. 1993. Narrative analysis. Thousand Oaks, CA: Sage.

Riessman, C. K. 2011. What's different about narrative inquiry? Cases, categories and contexts. In D. Silverman (Ed.), Qualitative research (3rd ed.): 310-330. Thousand Oaks, CA: Sage.

Rojas, F. 2010. Power through institutional work: Acquiring academic authority in the 1968 Third World Strike. Academy of Management Journal, 53: 1263-1280.

Rowlinson, M. 1988. The early application of scientific management by Cadbury. Business History, 30: 377-395.

Rowlinson, M., Booth, C., Clark, P., Delahaye, A., \& Procter, S. 2010. Social remembering and organizational memory. Organization Studies, 31: 69-87.

Rowlinson, M., \& Hassard, J. S. 2013. Historical neoinstitutionalism or neo-institutionalist history? Historical research in management and organization studies. Management \& Organizational History, 8: 111-126.
Roy, W. G. 1990. Functional and historical logics in explaining the rise of the American industrial corporation. Comparative Social Research, 12: 19-44.

Ruef, M., \& Harness, A. 2009. Agrarian origins of management ideology: The Roman and Antebellum cases. Organization Studies, 30: 589-607.

Schein, E. H. 1985. Organizational culture and leadership: $A$ dynamic view. San Francisco: Jossey-Bass.

Scott, J. 1990. A matter of record: Documentary sources in social research. Cambridge: Polity.

Sewell, W. H. J. 2005. Logics of history: Social theory and social transformation. Chicago: University of Chicago Press.

Shenhav, Y. 1999. Manufacturing rationality: The engineering foundations of the managerial revolution. New York: Oxford University Press.

Shenhav, Y., \& Weitz, E. 2000. The roots of uncertainty in organization theory: A historical constructivist analysis. Organization, 7: 373-401.

Shipilov, A. V. 2009. Firm scope experience, historic multimarket contact with partners, centrality, and the relationship between structural holes and performance. Organization Science, 20: 85-106.

Smets, M., Morris, T. I. M., \& Greenwood, R. 2012. From practice to field: A multilevel model of practice-driven institutional change. Academy of Management Journal, 55: 877-904.

Smith, G. E. 2007. Management history and historical context: Potential benefits of its inclusion in the management curriculum. Academy of Management Learning \& Education, 6: 522-533.

Sofsky, W. 1999. The order of terror: The concentration camp. (Translated by W. Templar.) Princeton, NJ: Princeton University Press.

Sonpar, K., \& Golden-Biddle, K. 2008. Using content analysis to elaborate adolescent theories of organization. Organizational Research Methods, 11: 795-814.

Spivak, G. C. 1988. Can the subaltern speak? In C. Nelson \& L. Grossberg (Eds.), Marxism and the interpretation of culture: 271-313. Urbana: University of Illinois Press.

Stager Jacques, R. 2006. History, historiography and organization studies: The challenge and the potential. Management \& Organizational History, 1: 31-49.

Stinchcombe, A. L. 1990. Information and organizations. Berkeley: University of California Press.

Stone, L. 1979. The revival of narrative-Reflections on a new old history. Past \& Present, 85(1): 3-24.

Strati, A. 2000. Theory and method in organization studies. Thousand Oaks, CA: Sage.

Suddaby, R., Foster, W. M., \& Mills, A. J. 2014. Historical institutionalism. In M. Bucheli \& R. D. Wadhwani (Eds.), Organizations in time: History, theory, methods: 100-123. Oxford: Oxford University Press.

Suddaby, R., Foster, W. M., \& Trank, C. Q. 2010. Rhetorical history as a source of competitive advantage. Globalization of Strategy Research, 27: 147-173. 
Suddaby, R., \& Greenwood, R. 2005. Rhetorical strategies of legitimacy. Administrative Science Quarterly, 50: 35-67.

Sutton, R. I., \& Staw, B. M. 1995. What theory is not. Administrative Science Quarterly, 40: 371-385.

Sydow, J., Schreyögg, G., \& Koch, J. 2009. Organizational path dependence: Opening the black box. Academy of Management Review, 34: 689-709.

Thornton, P. H., Ocasio, W., \& Lounsbury, M. 2012. The institutional logics perspective: $A$ new approach to culture, structure, and process. Oxford: Oxford University Press.

Tolbert, P. S., \& Zucker, L. G. 1983. Institutional sources of change in the formal structure of organizations-The diffusion of civil-service reform, 1880-1935. Administrative Science Quarterly, 28: 22-39.

Tosh, J. 2008. Why history matters. Basingstoke, UK: Palgrave Macmillan.

Tsoukas, H. 1989. The validity of idiographic research explanations. Academy of Management Review, 14: 551-561.

Üsdiken, B., \& Kieser, A. 2004. Introduction: History in organisation studies. Business History, 46: 321-330.

Van de Ven, A. H. 1992. Suggestions for studying strategy process: A research note. Strategic Management Journal, 13(Special Issue): 169-188.

Van Fleet, D. D., \& Wren, D. A. 2005. Teaching history in business schools: 1982-2003. Academy of Management Learning \& Education, 4: 44-56.

Van Maanen, J. 1988. Tales of the field: On writing ethnography. Chicago: University of Chicago Press.

Van Maanen, J. 1995. Crossroads: Style as theory. Organization Science, 6: 133-143.

Venkataraman, S., Sarasvathy, S. D., Dew, N., \& Forster, W. R. 2013. Of narratives and artifacts. Academy of Management Review, 38: 163-166.

Veyne, P. 1984. Writing history; Essay on epistemology. (Translated by M. Moore-Rinvolucri.) Middletown, CT: Wesleyan University Press.

Wadhwani, R. D., \& Bucheli, M. 2014. The future of the past in management and organizational studies. In M. Bucheli \& R. D. Wadhwani (Eds.), Organizations in time: History, theory, methods: 3-31. New York: Oxford University Press.
Walsh, W. H. 1967. An introduction to philosophy of history (3rd revised ed.). London: Hutchinson.

Weber, M. 2009. From Max Weber: Essays in sociology. (Edited by H. H. Gerth \& C. W. Mills.) New York: Routledge.

Weick, K. E. 1995. What theory is not, theorizing is. Administrative Science Quarterly, 40: 385-390.

Wertsch, J. V. 2011. Beyond the archival model of memory and the affordances and constraints of narratives. Culture \& Psychology, 17: 21-29.

Whipp, R., \& Clark, P. 1986. Innovation and the auto industry. London: Frances Pinter.

White, H. 1987. The content of the form: Narrative discourse and historical representation. Baltimore: Johns Hopkins University Press.

White, H. 1995. Response to Arthur Marwick. Journal of Contemporary History, 30: 233-246.

Wuthnow, R. 1989. Communities of discourse: Ideology and social structure in the Reformation, the Enlightenment, and European socialism. Cambridge, MA: Harvard University Press.

Yanow, D., \& Geuijen, K. 2009. Defining "organizational ethnography": Selection criteria. In S. Ybema, D. Yanow, H. Wels, \& F. Kamsteg (Eds.), Organizational ethnography: Studying the complexities of everyday life: 253-259. Thousand Oaks, CA: Sage.

Yates, J. 1989. Control through communication: The rise of system in American management. Baltimore: Johns Hopkins University Press.

Zald, M. N. 1993. Organization studies as a scientific and humanistic enterprise-Toward a reconceptualization of the foundations of the field. Organization Science, 4: 513-528.

Zald, M. N. 1996. More fragmentation? Unfinished business in linking the social sciences and the humanities. Administrative Science Quarterly, 41: 251-261.

Zickar, M. J., \& Carter, N. T. 2010. Reconnecting with the spirit of workplace ethnography: A historical review. Organizational Research Methods, 13: 304-319.

Zieman, B., \& Dobson, M. 2009. Introduction. In B. Zieman \& M. Dobson (Eds.), Reading primary sources: The interpretation of texts from nineteenth and twentieth century history: 1-18. New York: Routledge.

Michael Rowlinson (m.rowlinson@qmul.ac.uk) is professor of organization studies at Queen Mary University of London in the School of Business \& Management. He received his Ph.D. at Aston University. His current research interests are in organizational history and organizational remembering, focusing on how organizations represent history in the present.

John Hassard (john.hassard@mbs.ac.uk) is professor of organizational analysis at the University of Manchester. He received his Ph.D. at Aston University. His current research interests are in organizational history, corporate restructuring, and the management of healthcare.

Stephanie Decker (s.decker@aston.ac.uk) is senior lecturer in international business at the Aston Business School, Aston University. She received her Ph.D. at the University of Liverpool. As a historian working at a business school, her research is concerned with the nexus between organization theory and business history. 